\title{
The Post-COVID-19 New Normal Tourism: Concerns and Criteria
}

\author{
Galal M. H. Afifi
}

Department of Tourism, Faculty of Arts and Social Sciences, Sultan Qaboos University, Oman

Department of Tourism, Faculty of Tourism and Hotels, Helwan University, Egypt.

\section{ARTICLE INFO}

Keywords:

Tourism, COVID-19; post-COVID-19; tourism crises; new normal tourism.

\section{(JAAUTH) \\ Vol. 20, No. 2, (2021), \\ PP. 108-131.}

\section{ABSTRACT}

COVID-19 is undoubtedly an unprecedented crisis that hit tourism heavily, which resulted in enormous losses on different fronts. To date, tourism stakeholders are uncertain about the duration required for tourism to recover fully. The present calls for a quick resumption of tourism to save the massive investments and the millions of jobs currently at risk are challenged by numerous fears and concerns. However, unlike the uncertainty regarding the recovery duration, there is a noteworthy agreement that pre and postCOVID-19 tourism will be significantly different, as both tourist products and tourists' characteristics will witness evident changes either temporarily or permanently. In this regard, this research aims to investigate the concerns of postCOVID-19 tourism as well as to identify the features of what is now well-known as "the new normal tourism". The research resulted in identifying some of the potential features of "the new normal tourism", such as the length of travel and the potential tourists' characteristics.

\section{Introduction}

Tourism is one of the fastest-growing sectors and is an essential driver of economic growth and development (UNCTAD, 2020). According to the United Nations World Tourism Organization (UNWTO), international tourist arrivals have shown a substantial increase from 25 million tourists in 1950 to 1.5 billion tourists in 2019 , despite occasional crises (UNWTO, 2017 \& 2020a). In its long-term forecast "Tourism Towards 2030", the UNWTO expected the number of international arrivals to jump to 1.8 billion by 2030 (UNWTO, 2011). UNWTO reports have as well affirmed repeatedly the escalating importance of tourism on different scales, especially on economic and cultural aspects. For instance, eight years ago, the World Travel and Tourism Council (WTTC) estimates that at $9.1 \%$ of global GDP, Travel \& Tourism generates more economic output than automotive manufacturing $(7.9 \%)$, mining (8.0\%), and chemicals manufacturing (9.0\%) (WTTC, 2012). Thus, based on its current massive revenue of more than US\$ 1.7 trillion (10.3\% of global GDP) in 2018 (UNWTO, 2019a), tourism has been, for a long time now, in the "big business" league. Moreover, travel and tourism are considered global leading job creators, sustaining 330 million jobs in 2019, which represents about $9.2 \%$ of world 
employment (WTTC, 2020b), as well as a significant amount of indirect jobs in other sectors such as transportation, construction, catering, handicrafts, and souvenirs (UNCTAD, 2020).

Such importance gives the sector its contemporary significance. On the country level, tourism has been addressed as the main contributor to the GDP of numerous countries (e.g., the Bahamas, Greece, Thailand), as well as being a significant contributor in the case of tens of countries all over the world (e.g., France, South Africa, Mexico). However, this enormous contribution of tourism to both developed and developing countries has its drawback too, as any downturns in the level of activity in the industry will likely have a more devastating impact and will affect a larger segment of the global population (Pforr \& Hosie, 2008). This impact will be more influential, considering tourism early mentioned relationships with other sectors. "The repercussions extend beyond activities directly associated with tourism (notably, airlines, hotels, and catering), to those supplying intermediate or final goods purchased by firms and employees in the industry, so that all sectors of the economy are affected to a greater or lesser extent" (Blake and Sinclair, 2004: 813). Thus, it should be anticipated that a crisis hitting tourism will mostly have a higher impact on the global economy than a crisis hitting most of the other sectors.

\section{Tourism Crises}

Over its contemporary history, tourism has witnessed no shortage of threats to its stability, as the sector has been through numerous crises of different natures and magnitudes (Ritchie \& Jiang, 2019). The Asian (1997), the Greek (2007 - 2008) and the Spanish (2008 - 2014) financial crises, Iceland volcanic eruptions (2010), the repeated terrorist attacks in destinations such as New York (2001), Nairobi (2013), Paris (2015), and Nice (2016), wars in countries such as Ukraine, Syria, and Yemen, the foot-and-mouth outbreak (2001), the SARS (2002), Ebola (2007 \& 2013 - 2016), and Swine Flu (2009) epidemics have each made their impact felt on tourism. However, except for the combination of the European financial crisis and the Swine Flu in 2009, the UNWTO statistics record that none of these incidents curbed the growth of the global international arrivals, which were increasing in an almost regular pattern between 1950 and 2019 (UNWTO, 2017 \& 2020a). Actually, the impact of these crises was significantly evident on the destination level. For instance, the Indian Ocean Tsunami in 2004 caused a "reduction of tourist movement in this part of the world in 2005 by almost 40\% compared to 2004" (Blazin et al., 2016: 179). The Ukrainian war decreased the number of international arrivals to Ukraine from 24.7 million in 2013 to 14.3 million in 2018 (UNWTO, 2019b). Paris terrorist attacks in 2015 slashed $2.5 \%$ of the number of international arrivals to France in 2016 (World Bank, 2020). On the other hand, the only global impact emerged in 2009 as "the global economic crisis aggravated by the uncertainty around the A(HINI) pandemic turned 2009 into one of the toughest years for the tourism sector" (UNWTO, 2010: 3).

In this respect, some researchers have recently started establishing a conviction that the tourism sector has cumulated good knowledge and experience in managing crises. Two key indicators supported this assumption. First, it can hardly be denied that there 
are a plethora of studies that have thoroughly investigated the various crises that hit the tourism sector, especially in the last 20 years. For instance, researchers such as Papatheodorou et al. (2010), Song \& Lin (2010) studied the consequences of the global economic crisis on tourism in general. Other researchers explore the same impact on whole continents such as Europe (Smeral, 2009), Asia (Song and Lin, 2010), North America (Ritchie et al., 2010), or specific destinations such as Serbia (Sekulovic, 2015), Cyprus (Boukas \& Ziakas, 2013) and Poland (Roman, 2015). Tens of papers have been published on the impact of the Swine Flu (e.g., Page et al., 2012; Strielkowski, 2014), and the SARS (e.g., Wen, 2005; Cooper, 2008). Similar efforts can easily be observed in examining, analyzing, and documenting other crises and their impact on tourism. That is besides the numerous reports, guidelines, and manuals issued by official international or local tourism institutions and authorities (e.g., UNWTO, WTTC, IHO) to document each crisis timeline, impact, action plans, and lessons to be learned.

Second, tourism was typically seen as an industry that "is highly susceptible to negative events and, since there is always a crisis somewhere in the world, the sector appears to be under an almost permanent threat of yet another crisis looming" (Pforr \& Hosie, 2008: 249). As McKercher and Hui (2004: 101) stated, "crises are inevitable, episodic events that disrupt the tourism and hospitality industry on a regular basis". Coles (2004: 178) added, "when not in crisis, destinations are in an extended program of practically pre-event limbo, almost waiting for the important trigger event to take place" (cited in Pforr \& Hosie, 2008:249). In contrast, it recently becomes more common to find studies describing tourism as a resilient sector (e.g., Cheer \& Lew, 2017; Filimonau \& Coteau, 2020) rather than the deeply-rooted, classic description as a vulnerable sector (e.g., Clements \& Georgiou, 1998; Ioannides \& Apostolopoulos, 1999; Sausmarez, 2004). Actually, on more than one occasion, tourism shows that it is resilient more than stereotypically expected. For instance, just three months after the Indian Ocean Tsunami in 2004, the UNWTO Emergency Task Force announced that "the tourism sector in the affected regions had experienced a swifter than expected return to business for tourism enterprises and facilities" and that "much has been achieved in the short term, and tourism has proved to be resilient with the rallying force and the unity of the international community to support it" (2005: 7). Severe direct terrorist attacks against tourist facilities in countries such as Jordan (2005) and Egypt (1997 \& 2004) left the sector almost unharmed despite the then pessimistic expectations for several years of deterioration. Such crises initiated the sector's new reputation as "more resilient than expected". Such realities played a crucial role in shifting the tourism experts to be more optimistic and confident in the sector resilience. Today, this gaining-ground assumption is seriously challenged by what is undoubtedly the harshest tourism crisis in contemporary tourism records.

On the other hand, tourism usually observes significant changes during the post-crisis period, generally as a response to the crisis impact and the generating markets' anticipated reactions, whether these changes are directly or indirectly linked to the tourism product. Directly-linked changes could take the form of (1) offering new products. For instance, Egypt decided in the mid-1990s to shift from mainly 
promoting cultural tourism in the Nile Valley destinations (e.g., Cairo, Luxor) to recreational tourism on the Red Sea (e.g., Sharm El Sheikh, Hurghada) to avoid the repetitive terrorist attacks on tourists in the overcrowded valley as well as to respond to the expected demand decline on the Nile Valley sites. (2) Rebranding tourist destinations. In Egypt again, after the 25th January revolution, Egypt wanted to disassociate itself from its negative past of political instability and violence, including terrorism attacks, street demonstrations, public disorder, enforced curfews, etc. As a result, a plan was suggested to rebrand Sharm El Sheikh (Amara, 2016). Indirectly, numerous examples can be given. For instance, After September 11, most of the American and then most of the world airports started applying more precautional and restricted procedures (Blake and Sinclair, 2004). After the Indian Ocean Tsunami, early warning systems were installed in Indonesia and Thailand (UNWTO, 2005).

Thus, it could be noted that despite the incremental conviction in tourism resilience, tourism post-crisis periods are usually associated with significant concerns and notable direct or indirect changes.

\section{COVID-19}

On December 31, 2019, the World Health Organization (WHO) Country Office in the People's Republic of China picked up a media statement by the Wuhan Municipal Health Commission from their website on cases of "viral pneumonia" in Wuhan, People's Republic of China. On January 4, 2020, the WHO tweeted that there was a cluster of pneumonia cases - with no deaths - in Wuhan, and that investigations to identify the cause were underway. Then on January 9, it was the WHO reported for the first time that a novel coronavirus causes the outbreak. On January 13, Thailand reported the first case outside China, which was followed up by a WHO announcement that COVID-19 could potentially transmit from human-to-human (WHO, 2020a). Afterward, reports started to accelerate from different countries, announcing cases on their territories, including the announcement of the first confirmed case in the USA on January 21, Europe (France) on January 24, and the Middle East (UAE) on January 29. By the end of January, 98 cases were confirmed without any death in 18 countries outside China. On February 11, WHO announced that the disease caused by the novel coronavirus would be named COVID-19 (WHO, 2020a).

March 7 marks the number of confirmed COVID-19 cases surpassing 100,000 persons globally. This was followed by a shocking WHO announcement that by the alarming levels of spread and severity of the inactions, COVID-19 could be characterized as a pandemic. Then on April 4, WHO reported that over one million cases of COVID-19 were confirmed worldwide, a more than tenfold increase in less than a month (WHO, 2020a). By April 20, the UNWTO (2020d) declared that 100\% of the countries were applying some travel restrictions, to mark the moment of hitting the tourism sector with what is to be considered the harshest crises ever. Accordingly, the International Air Transport Association (IATA) recorded that air traffic levels for 2020 are expected to fall by $54.7 \%$ compared to 2019 (IATA, 2020a). To date (September 10,2020), the number of confirmed cases passes the barrier of 28 million, 
with a daily average of almost 250,000 new cases during the last week (Worldometers, 2020).

Since the onset of the pandemic, tourism realities have started to shift tremendously. Countries started applying different travel restrictions, ranging in severity from total borders lockdown for non-residents to applying institutional quarantine or selfisolation for arriving travelers. "As a result, international tourism has been almost totally suspended, and domestic tourism is curtailed by lockdown conditions imposed in many countries" (UNCTAD, 2020: 6). Only during the first quarter of 2020, COVID-19 caused a 22\% fall in international arrivals (UNWTO, 2020b), which may slump as much as $78 \%$ of the international arrivals in 2020 compared to 2019 (World Economic Forum, 2020a). According to three possible future scenarios (i.e., opening up in early July, September, or December 2020), the year 2020 is expected to conclude with 850 million to 1.1 billion fewer international tourists, US\$ 910 billion to US\$ 1.2 trillion losses in tourism revenues, and putting 100 to 120 million direct tourism jobs at risk (UNWTO, 2020b). This estimation is even more worrying, considering that tourism is a leading economic catalyst for several other sectors (ILO, 2017).

In this respect, until 2020, the Indian Ocean Tsunami in 2004 was recorded as the worst disaster in the history of global tourism, claiming the severest financial damage and biggest lives loss of tourists and tourism workers (UNWTO, 2005). Globally, referring to the UNWTO (2020b \& c), UNCTAD (2020), World Economic Forum (2020a), and Organisation for Economic Co-operation and Development reports, researchers can reasonably claim now that, given the immediate and immense damage happening, the impacts of COVID-19 has, by far, exceeded those of the Indian Ocean Tsunami, and COVID-19 pandemic has placed itself as the severest ever crisis to hit the tourism in the historical series of international tourism since 1950 (OECD, 2020). At the country level, the impact differs depending on the contribution of the tourism sector to each specific destination. Least developed countries, small island states, and countries such as Mexico with 15.5\% of its GDP relying on tourism, Spain (14.3\%), and Italy (13.0\%) are also vulnerable (UNCTAD, 2020; World Economic Forum, 2020b). On the other hand, MICE tourism gives just one example of the suffering tourism sub-sectors. Around the globe, companies have canceled or suspending business travel, in some cases, until 2021. Events of all sizes have also been affected, including the 2020 Olympic Games. By 20 March, the Global Association of the Exhibition Industry estimated that more than 500 trade shows had been canceled in the preceding weeks, with an estimated cost of up to EUR 23 billion in lost orders for exhibitors. On 20 March, UFI estimated that at least EUR 134 billion of contracts will not be concluded if events do not take place as planned through Q2 2020 (OCED, 2020).

Screening the previously mentioned reports indicate that there is no guarantee that 2021 will regain the numbers of 2019 as tourism will mostly go through long-term gradual recovery. Confirming the same assumption, the WTTC (2020b) claims that "tourism is likely to recover more slowly than other industries, perhaps as long as 19 months, based on experience gained from previous pandemics". IATA records as 
well that "with open borders and rising demand in 2021, the industry is expected to cut its losses to $\$ 15.8$ billion for a net profit margin of $-2.6 \%$. Airlines will be in recovery mode but still well below pre-crisis levels of 2019" (IATA, 2020a). During that period, tourism will be dramatically reformed and launched into a different era, which is widely known now as the "new normal tourism". Some features of this new era have already been defined and widely accepted; meanwhile, more efforts are still going on to portray a full image of it.

\section{Research aim}

With all its well-recorded contributions, the world can't, of course, afford losing or shutting down the tourism sector forever; and, whether the efforts for finding a valid cure are to end successfully sooner or later, tourism will start again. Thus, the tourism sector should wisely end the time of counting losses to begin thinking about postCOVID-19 tourism, which is happening now. In this context, the tourism sector may need to recall John F. Kennedy's statement that "when written in Chinese, the word crisis is composed of two characters - one represents danger, and the other represents opportunity." This statement actually reflects the two challenges that tourism should handle in the post-COVID-19 era: Concerns and criteria of "new normal tourism".

On the one hand, researchers such as Hitchcock \& Putra (2005), Hall (2010), and Mair et al. (2016) argue that the end of a particular crisis does not always result in an immediate tourism recovery as the crisis impact usually extends behind the end of the crisis itself. For instance, despite the positive indication of economic recovery after the global financial crisis in 2008, unemployment was still increasing in key tourism generating markets, exchange rates, and oil prices were still fluctuating, and restrictions in bank credit facilities remained, which jointly extended the duration of the crisis impact over 2009 (Papatheodorou et al., 2010). Thus, it could be expected that post-COVID-19 tourism will still face some concerns, which may hinder a swift recovery. On the other hand, researchers are frequently affirming now that postCOVID-19 tourism will never resemble pre-COVID-19 tourism. Thus, a new term was coined and widely circulated to express the anticipated changes: "New normal tourism". Accordingly, this research aims to investigate the concerns and potential features of post-COVID-19 tourism.

\section{Research Methodology}

Unlike several previous studies on tourism crises (e.g., Boukas \& Ziakas, 2013; Ooi et al., 2014; Roman, 2015), this study is not focusing on analyzing the statistical data to assess the impact of a crisis empirically or to develop a formula to foresee future trends, but rather to review and analyze the current ideas and knowledge about a crisis (i.e., COVID-19) with an ultimate aim to shed light on the concerns of and the potential changes in post-COVID-19 tourism. Thus, resembling the work of Mair et al. (2016: 3-4), "since the data for this review [the reports collected] report on a combination of qualitative and quantitative research, ... a narrative approach was taken". According to Mays et al. (2005), the narrative approach allows for the synthesis of evidence drawn from a number of studies, reports, or documents, both qualitative and quantitative. In other words, the narrative approach moves beyond a 
simple summary of the findings of various studies, reports, or documents in a bid to generate new insights or conclusions (Mays et al., 2005, cited in Mair et al., 2016). In this regard, it should be mentioned that narrative review, and content analysis have been widely employed as a competent data-collection method (Punch, 1998), including gathering data from sources such as journals, official records, official websites, and visual documents (e.g., films) (Jupp, 1996), where contents "rather than acting as an introduction to the research...take on a central role as the actual thing that is to be investigated" (Denscombe, 1998: 158).

In this context, this research will rely on investigating recent reports on tourism and COVID-19 published by official local and international organizations ,e.g., UNWTO, WTTC, ICAO, German Federal Foreign Office, UK Home office), as well as reviewing studies on previous tourism crises to identify any similarities and conclude any learned lessons. The relevant documents were examined over the period between April and August 2020, where they were well searched for related data. The narrative review was useful for understanding the concepts and procedures related to COVID19, the potential plans, and the expectations of different organizations, institutions, and experts.

\section{Findings}

\section{Post-COVID-19 tourism concerns}

The tourism post-crisis phase is usually associated with numerous concerns and hazards (Hitchcock \& Putra, 2005). In the case of COVID-19, this list may include the following concerns:

\section{Travel restrictions}

On January 10, the WHO issued its first of seven advice notes regarding travel and COVID-19, stating that "while the cause of the pneumonia seems to be a novel coronavirus, transmission potential and modes of transmission remain unclear. Therefore, it would be prudent to reduce the general risk of acute respiratory infections while travelling in or from affected areas (currently Wuhan City)" (WHO, 2020b). On the same note, the WHO suggested that "health practitioners and public health authorities should provide to travellers information to reduce the general risk of acute respiratory infections, via travel health clinics, travel agencies, conveyance operators and at points of entry" (WHO, 2020b). Most importantly, the WHO notified that regarding international traffic, no restrictions were recommended as no cases were reported outside Wuhan City. A second note was issued, on January 24, announcing that "travel-related cases linked to Wuhan City have been reported in several countries" and advising that "measures to limit the risk of exportation or importation of the disease should be implemented, without unnecessary restrictions of international traffic" (WHO, 2020c), before providing a list of advice for exit and entry screening to be applied to international travelers. Only three days later, the WHO issued its third advice note, including minimal adjustments regarding the procedures of exit and entry screening (WHO, 2020d).

On February 11, the fourth note was issued recording that "WHO did not recommend any travel or trade restrictions, based on the current information available", and 
suggesting measures to be adopted if a country decided to repatriate their nationals from Wuhan City, as well as five lists of advice named: Onboard the aircraft, upon arrival at the point of entry, suspected cases detected at arrival, non-suspected passengers' arrival into the country, and quarantine (WHO, 2020e). A fifth note was issued, on February 29, where the WHO continued "to advise against the application of travel or trade restrictions to countries experiencing COVID-19 outbreaks", although notifying that "it is prudent for travellers who are sick to delay or avoid travel to affected areas, in particular for elderly travellers and people with chronic diseases or underlying health conditions" (WHO, 2020f). A joint ICAO-WHO statement was then issued on March 11 to address the cooperation between the two organizations (ICAO \& WHO, 2020). Finally, on July 30, a seventh note was issued about public health considerations while resuming international travel.

Accordingly, it can hardly be claimed that WHO recommendations were underlying any international travel restrictions. However, it was actually up to each country to define whether to apply any restrictions or not. Aiming to mitigate the spread of the Corona Virus, by April 20, 100\% of worldwide destinations introduced travel restrictions (UNWTO, 2020d; World Economic Forum, 2020a). In the interests of preserving public health, a sizable number of governments worldwide chose to close their borders for some time entirely. Other countries decided to ban entry to nonresidents (e.g., India, Malaysia, South Africa) (Nunes, 2020), and prevent their citizens from traveling either internationally (e.g., Germany, Italy) or even domestically by applying a lockdown between local regions (e.g., Oman). On February $1^{\text {st }}$, Australia, for instance, halted the entry of travelers from China except for Australian citizens and permanent residents who were ordered to self-quarantine for 14 days. Australia subsequently imposed travel bans on Iran (1 March), South Korea (5 March), and Italy (11 March). A general travel ban with limited exceptions, on non-citizens and non-residents traveling to Australia and Australians traveling overseas, was then activated on 20 March (Home Affairs, 2020). Almost the same travel restrictions were applied in other countries with different dates and minimal details.

On the other hand, fewer countries didn't ban travel, yet health regulations were implemented. For instance, the UK has kept an open-border policy, where about 15,000 passengers were arriving at its airports each day. However, arrivals are obligated to complete a passenger locator form and to self-isolate for 14 days, whether they are citizens or visitors (Gov.UK, 2020). The European Union has applied entry restrictions for non-essential travel from non-EU countries since March 17. On June 30, the European Union adopted a recommendation on relaxing the entry restrictions (Federal Foreign Office, 2020), where travelers coming from outside the European space are encouraged to have a negative PCR or may have the test in the arrival airport (France Diplomacy, 2020). July and early August witnessed resuming international travel in several countries, regardless of the incremental number of infected cases. "As the situation evolves, countries increasingly adopted tourismspecific measures to reopen and restart the sector. This is particularly noticeable for 
countries in which tourism is a significant contributor to the national economy" (UNWTO, 2020e: 6).

Finally, since the onset of the COVID-19 pandemic, decisions regarding tourism and travel restrictions have not been mainly in the hand of the tourism decision-makers, whether nationally or internationally, as other authorities, especially health ones, became key partners. Thus, the future tourism decision-making process will mostly be multisectoral to ensure coordination of the measures implemented by national and international health and transport authorities and other relevant sectors and be aligned with the overall national strategies for adjusting public health and social standards (WHO, 2020g). Such interlaced relationships could be a concern, by itself, as any subsequent regulations must be proportionate to a significant number of authorities. As well, the fear of a second wave of the pandemic, and therefore the possibility of reapplying restricted travel regulations either domestically or internationally in the future, represent the foremost concern of the tourism business.

\section{Tourist demand decline}

Official reports (e.g., UNWTO, 2005, 2010, \& 2020b) prove clearly that tourism crises have an inverse relationship with tourism demand, especially international arrivals. Researchers such as Salleh et al. (2008), Lean and Smyth (2009) even argue that tourist demand decline is the foremost impact in the tourism post-crisis periods. For instance, Habibi et al. (2009), Hanafiah \& Harun (2010), and (Ooi et al., 2013) found out that crises like natural disasters, disease outbreaks, economic crises, and terrorism significantly affect international tourism demand in Malaysia. Page et al. (2012) proved that the 2008 financial crisis and the Swine Flu pandemic had had significant negative impacts on the tourist demand to the UK. Researchers such as Blake and Sinclair (2004), Pambudi et al. (2009), and Wendt (2019) came to the same conclusion in other countries such as the USA after September 11 attacks in 2001, Malaysia after the Bali bombing in 2005, and Egypt and Tunisia after political instability between $2010-2015$. In this context, it may worth mentioning that few crises may have a positive impact on tourist demand (e.g., depreciation of the local currency rate of exchange in some tourism destinations) (Aki 1998).

Recently, the UNWTO started publishing reports (UNWTO, 2020d \& e) pointing to the efforts made in several destinations to reopen to the visitors, offset the downturn, and stem the losses. These reports indicated that destinations will hardly experience swift returns to their customary levels of demand soon and that the medium-term outlook remained negative. Early enough, tourism researchers were aware of the reasons underlying such retrograde demand attitude as "tourism analysts seem to share the view that international visitors are very concerned about their personal safety" (Edgel, 1990: 119) and that "tourism can only thrive under peaceful conditions" (Pizam \& Mansfield, 1996: 2 cited in Hitchcock \& Putra, 2005), where "personal safety" can be interpreted in different perspectives (e.g., physical, emotional, mental). Blake and Sinclair (2004) record as well that tourism demand is particularly sensitive to security and health concerns. Thus, it is rational to witness the current sharp downturn in tourism demand, which will mostly continue as far as "personal safety" - in this case, health safety - is a concern. Second, the uncertainty 
about the depth and impacts of the potential global recession following COVID-19 and, therefore, the explosively growing threat of unemployment, loss of income, loss of assets value, and the safety of savings, will inevitably lead to a slowdown in tourism demand recovery (Beirman, 2003; Smeral, 2009). Another factor is the postcrisis fear of traveling, especially to far or new destinations, which could go as extreme as being phobiatic (i.e., hodophobia). Statements such as "There is no "zero risk" when considering the potential importation or exportation of cases in the context of international travel" (WHO, 2020g) may stimulate that fear. In this context, UNCTAD (2020) records that although some destinations have started slowly to open up, individuals are still afraid of traveling or simply can't afford it.

\section{Tourist supply failure}

COVID-19 is not just a health pandemic but also an economic crisis on a global scale (UNCTAD, 2020). Thus, tourist demand may recover to face a tourist supply problem. Current reports reveal that in each country, hundreds if not thousands of projects have been bankrupted, including tourism projects. For instance, $23 \%$ of hotels in Switzerland considered bankruptcy "likely" during a survey conducted in March 2020, as a consequence of COVID-19 (Statista, 2020). According to a study by the Hellenic Chamber of Hotels, 65\% of Greek hoteliers say that bankruptcy of their business is either "likely" or "most likely" (Wood, 2020). Small and medium-sized enterprises (hereafter SMEs) are another weak spot in the tourism post-crisis supply, as a majority of tourism enterprises are SMEs of less than 50 employees (ILO, 2020). Given their often-limited resources and existing obstacles in accessing capital, the period over which SMEs can survive a shock will likely be shorter than for larger firms (OECD 2020). As well, projects in the least developed countries are highly vulnerable to crises and, thus, are among the most impacted by COVID-19 (UNCTAD, 2020). In this context, it may worth mentioning that many tourism destinations are among the least developed countries.

Shedding more light on the concerns facing tourism enterprises, the UNWTO dedicated the first issue of its Tourism and COVID-19 Briefing Note to offer an overview of the primary measures adopted by countries to mitigate the immediate effects of COVID-19 and facilitate the business recovery in 220 countries and territories (UNWTO, 2020e). The Note records that "by far the most common measures adopted by countries are economy-wide fiscal stimulus packages", which commonly include "exemptions or deferrals of VAT and corporate income tax, emergency economic funds, and economic assistance, especially to SMEs and selfemployed and investment programmes" (UNWTO, 2020e: 6). In a major sign of cooperation, several international institutions such as the International Monetary Fund, the World Bank, the Organization for Economic Co-operation and Development, and United Nations agencies have largely supported countries, especially with programs for SMEs, self-employment, and job protection through different mechanisms (UNWTO, 2020e).

The Post-COVID-19 tourism supply will face multiple difficulties. Part of the enterprises which will survive the current crisis will come back to business in partial capacity either to meet official rules (e.g., Egypt), or to get more time to assess the 
market new requirements and therefore adjust their product, or simply to reduce costs considering the anticipated low demand. However, the main problem will be the bankruptcy and, therefore, the permanent shutdown of a countless number of tourism projects, which will mostly lead to a noteworthy reduction in the tourism facilities and services. Finally, COVID-19 will also have a long-term impact on tourism investment, as Ooi et al. (2013) notify that tourism crises could result in failing to obtain future investment, especially in small island states, which are over-reliant on foreign investment (Boukas \& Ziakas, 2013). Several SMEs will never be able to restart again at all. Keeping up to any new obligatory requirements (e.g., new ventilation systems, building partitions between tables) will need liquidity, which will surely be out of the capability of several SMEs, especially after such a lengthy lockdown sans revenue. Thus, it is not surprising that the investment bank UBS predicted that up to one in five restaurants in the United States might close permanently; the majority of them will be SMEs (Sampson \& Compton, 2020).

Finally, the convention sector is probably the most endangered tourist activity. With the current expansion in using online meetings, this attitude may continue, at least in the near future, to devastate this sector entirely. In this regard, it might be reasonable to argue that the tourism supply could be another concern in the post-COVID-19 tourism era.

\section{Air passenger traffic collapse}

COVID-19 pandemic and its consequences on economic recession, employment, investment, and demand were not confined to the tourism business only but extended to include other tourism-related sectors such as airlines. According to IATA, 77.2\% of the commercial passenger planes have been grounded between February and August 2020, due to COVID-19 (IATA, 2020a). During the same period, American airlines reported a $\$ 2.1$ billion net loss in the second quarter only; Cathay Pacific issues a statement, revealing that passenger numbers for the airlines dropped $99 \%$ compared to the same period in 2019; British Airways decided to retire its entire Boeing 747 fleet after the pandemic travel slump (IATA, 2020b). This is as well as the bankruptcy of several small airline companies (e.g., Ernest Airlines, Atlas Global, Air Italy, and Flybe). Summarizing the potential impact of the COVID-19 on the airline sector over 2020, ICAO (2020) reported that compared to business-asusual estimations, the impact would include: (1) An overall reduction ranging from $45 \%$ to $51 \%$ of seats offered by airlines, (2) an overall decrease of 2,579 to 2,893 million passengers, and (3) approximately US\$ 345 to 386 billion potential loss. In plain words and according to IATA Director General, "financially, 2020 will go down as the worst year in the history of aviation" (IATA, 2020c).

Such estimations indicate that the sufferance of the airline sector will mostly put an extra burden on tourism demand due to the expected increase in operational costs, and therefore in ticket prices, which will make it even harder to revive far distance tourism. However, previous experience reveals that airline companies owned by governmental entities (e.g., Egypt Air, Emirates, Etihad, Turkish Airlines) could be directed to provide competitive prices to facilitate tourism recovery, nevertheless their own financial loss. Uncertainty regarding the resumption of airline operations is 
another obstacle as over half of the announced/planned flights to be resumed between April and July were subsequently withdrawn (ICAO, 2020). With such a high degree of vagueness, planning for tours, which is usually done weeks to months in advance, is almost impossible. Debatable information about the possibility of infection as being locked in an airplane for hours as well raises a question regarding the duration needed to restore consumers' confidence in air travel (ICAO, 2020). Finally, any future scenarios depend on the borders reopening (World Economic Forum, 2020a).

\section{Uncertainty and misleading information}

Information plays a crucial role in tourism decision-making (Patterson, 2007), especially during post-crisis phases when tourists become in desperate need to know the situation in their potential destination. In post-crisis phases, tourists could be vulnerable to intentionally or unintentionally publicized false information, which can vitally affect their decision and, therefore, the destination recovery. In the case of COVID-19, the current ignoramus of a lot of the pandemic features is already producing much inaccurate information. For instance, the early uncertainty about COVID-19 methods of infection, the argument about the possibility of reinfection, the long debates regarding vaccines and valid medications, all have resulted in piles of inaccurate information, which may at most ignite the fear of traveling or at least lead to unnecessarily abandoning a lot of harmless tourist activities. To date, UNWTO and WHO projections reflect considerable uncertainty about the duration of the pandemic, in addition to the government decisions regarding travel restrictions (UNCTAD, 2020). On the other hand, unfair competition may lead some destinations to spread rumors or false information about the health situation in competitive destinations to hold them off the market for a while.

Such misleading practices are common in post-crisis phases. For instance, in 2005, President Bill Clinton, UN Special Envoy for Tsunami-affected countries, recorded a video message, appealing to the media for the accurate dissemination of information to the public on areas affected by the tsunami (UNWTO, 2005), aiming to face the widely spread false information about potential earthquakes and other tsunamis, which slowed down recovery in south Asian destinations.

In a crisis such as COVID-19, meticulous efforts will be needed to ensure the dissemination of accurate information about the destination and fight back intentional and unintentional false information. Studies on previous crises show that practices such as "live information platforms" feed by both professionals and the public and linked to international organizations' websites, and FAM and operators' trips from the main generating markets could help the destination promote facts and boost travelers' confidence. Destinations should also strongly urge stakeholders to consult their official site for more detailed information. Finally, it is rational that information about the spread of COVID-19, the precautional procedures, travel regulations, and health services' sufficiency and efficiency will be essential.

\section{Permanent loss of experienced workers}


With more than 330 million jobs all over the world in 2019 (WTTC, 2020b), including a significant amount of indirect employment in sectors such as transportation, construction, catering, handicrafts, and souvenirs (UNCTAD, 2020), tourism shows that it deserves its classic description as a labor-intensive sector. Tourism is accordingly responsible for $10.3 \%$ of total global employment (ILO, 2020). The accommodation and food services subsectors alone employ 144 million workers worldwide. Tourism also serves as a first entry point into work, especially for women, youth, migrant workers, and rural populations (ILO, 2013 \& 2020). For instance, $54 \%$ of these jobs are undertaken by women, significantly higher than in several other sectors. Tourism is as well able to accommodate individuals with different levels of skills, which helps low-skilled individuals in particular to find proper access to the job market.

As a result of COVID-19 and following the three scenarios announced by the UNWTO, WTTC (2020b) records that the tourism sector will lose between 98.2 million to 197.5 million jobs, where low-skilled, casual, and temporary workers are likely to be the first to lose their jobs or face pay cuts (UNCTAD, 2020). Referring to an ILO report (2020), about 30 percent of the total tourism workforce is employed in small firms with $2-9$ employees. The potentiality of these firms to survive is, as early mentioned, less than larger enterprises, which put the majority of their workers at immense risk of losing their jobs. This current situation may lead to a permanent loss of experienced tourism workers (e.g., guides moving to translation jobs, chefs moving to work for hospitals), who will be more capable of securing other jobs. It may also strengthen the negative reputation of tourism as a precarious career, which may lead to results such as decreasing tourism education attractiveness for new generations.

\section{Recovery costs}

On the level of both destinations and projects, the costs of recovery will be a concern. Natural disasters are usually associated with substantial re-development expenses (e.g., 3.3 billion \$US in the case of the Indian Ocean Tsunami) (Ooi et al., 2013). Considering the scale of the current crisis, the expenses will be phenomenal. On the destination level, financial capabilities are not required only for re-establishing destroyed infrastructure and tourist services, but also for several other aspects such as subsidizing SMEs, launching promotional plans, and reforming the destination image. On the project level, money is also required for a long list of necessities, such as adjusting services for any new requirements, re-hiring staff, maintenance, and promotional activities. The OECD (2020) highlights that SMEs may have less resilience and flexibility to cope with the costs that such shocks entail, with a survey of SMEs indicating there is a serious risk that over 50\% of SMEs will not survive the next few months, the other $50 \%$ will suffer long-term financial consequences due to the recovery costs.

\section{Criteria for new normal tourism}

Tourism organizations such as UNWTO and WTTC have been widely circulating the term "new normal tourism" to express the expected massive changes in the postCOVID-19 tourism sector. Changes are not confined to tourists' characteristics but will extend to include changes in the product features and the related operational 
procedures. The importance of noting these changes came from the high expectations that they may color the realm of tourism for the coming months or years. Some expectations even believe that these changes will reshape tourism forever, considering the assumption that "the new coronavirus might be here to stay", as announced by the World Health Organization's Emergency Director (BBC, 2020). In this respect, the criteria for the new normal tourism may include the following main features:

\section{Traveling distance}

Focusing on the traveling distance, OECD (2020) and UNWTO (2020c) believe that domestic tourism will recover faster than international tourism, offering a modest chance for initiating business recovery. As well, international tourism within specific geographic regions (e.g., the European Union) will start rebounding. This assumption is broadly supported by numerous previous studies (e.g., Smeral, 2009; Ritchie et al., 2010; Sekulovic, 2015), which proved that tourists preferred to stay close to their home countries or to travel domestically during post-crisis periods. The expected increase in air ticket prices due to the recommendations for limiting the airplanes' capacity and the incremental costs of operation will definitely escalate the tendency to avoid long-distance traveling.

\section{Destination wellness}

Tourism is particularly sensitive to security and health concerns (Blake and Sinclair, 2004). Screening statistics of the international arrivals on both global and destination level over the last 70 years proves that expressively (UNWTO, 2017 \& 2020a). Thus, tourists' safety is a key influential factor when making decisions. Accordingly, it is vastly believed that post-COVID-19 tourists' decisions will be highly influenced by the destination wellness, and availability and quality of health services (UNWTO, 2020e). Wellness indications such as the number of daily infected cases, the number of active COVID-19 cases, and the destination's overall commitment to safety regulations (e.g., how far is the society committed to precautional procedures) will all have a significant influence. In this regard, it is expected that global organizations such as the UNWTO and the WHO will play a key role in setting rules for the coming up period. Until the containment of COVID-19, official statements will mostly categorize countries into colored zones (e.g., green, yellow, orange, red) to identify the severity of the COVID-19 or the readiness to receive tourists. Countries will mostly keep issuing lists of what could be entitled "Green countries," which they can receive travelers from or to which their residents can travel. From another perspective, destinations may start looking for "certificates of wellness" to prove their safeness for visitors as destinations that fail in restoring confidence and proving health wellness will most probably not be able to attract a significant tourist demand.

On the other hand, ensuring the availability and efficiency of health services will also be a necessity. Indications such as the ratio of hospital beds per population and the quality of the health services and their cost will also be considered. Promoting the features of health services will also essential for establishing trust. On the service level, while "cleanness" was just one item on a long list of factors affecting the selection of a hotel or a restaurant when reserving on one of the websites, it might be a leading indicator in the coming months and maybe years. Practices such as hiring 
professional institutions for monitoring and maintaining distinguish health standards could be a norm for accommodation and catering facilities, which may target hospital-cleaning measures. For instance, Marriott has set up a "Cleanliness Council" to advise its global portfolio on best practices (World Economic Forum, 2020a). Quality certificates (e.g., ISO) may share the wall with COVID-19-Free certificates or such alike. In this context, several destinations have already published clear guides for the safe operation of different tourist services, including hotels and airports, as well as protocols for dealing with potential COVID-19 cases among tourists.

\section{Isolated tourism}

Safety measurements, including social-distancing and limited interaction, will also be key influencers in the "new normal tourism". Tourism types that classically attract a small number of travelers, as well as that include activities in wide-open sites (e.g., deserts, mountains, isolated islands and beaches), will expectedly gain more grounds as tourists may tend to what could be named "isolated tourism". Thus, types such as geo-tourism and eco-tourism, and outdoor activities in rural areas, for instance, where there is less possibility to interact with major crowds, will as well be more appealing. UNWTO experts (2020c) argue that leisure travel is expected as well to recover quicker, particularly for visiting friends and relatives. On the other hand, destinations depending on mass tourism could be the "big loser" of the coming period.

Isolation will not be confined to locations only but will extend to include a tendency to private travel as the pandemic will create a higher demand for experiences away from crowds. According to a US Travel Association survey, people feel more comfortable traveling in personal vehicles, whether owned or leased, than taking flights or cruises. Tourists will also be more interested in private accommodations facilities such as camping, rented apartments, villas, and private islands than staying in hotels (Sampson \& Compton, 2020).

\section{Less interaction with local communities}

Pre-COVID-19, active interaction between tourists and local communities was usually considered a sign of healthy tourism. As well, community involvement was well linked to different aspects of tourism practices and research such as sustainability, enhancing tourists' experience, and community-based tourism with a substantial aim of maximizing the mutual benefits for both communities and tourists. Adopting measurements of social distancing might lead to curbing many tourist activities that necessitate local gatherings. This may include activities such as visiting traditional markets, featured by their narrow alleys and overcrowded environment (e.g., traditional markets in Egypt, Oman, Morocco, Spain, and Italy), folklore activities in resorts (e.g., folklore parties in Peru, Mexico, Indonesia). Canceling or declining such activities will not only financially affect the local communities but will also reduce the required and favorable tourist/local community interaction, which will hinder tourists from getting real authentic experiences. Tending to visit isolated sites and types such as adventure, eco, and geo-tourism will as well reduce interaction with locals, as these types usually flourish away from major residential communities. More 
tourists will prefer to use their own facilities (e.g., camping or cooking facilities), which will as well reduce the involvement of local communities.

Wearing personal protective equipment (e.g., face mask) is also likely to become the norm. This should raise a concern regarding the possibility of diminishing the tourist's experience either physically (e.g., smelling the traditional markets scent) or emotionally (e.g., exchanging smiles with locals). Adhering to social distancing may also lead to reducing commercial activities as tourists may try to avoid evitable interactions. This may end encouraging "bubble destinations", where tourists' relationships with the hosting community are marginal. In the same context, the reaction of the local community and their willingness to interact and welcome tourists visiting their areas will also be a concern, especially in sites where local residents are not economically involved in the tourism business as they will see tourists as only an additional risk.

\section{Limited access to tourist services and attractions}

Pre-COVID-19, several destinations were restricting the number of daily visits to sensitive locations (e.g., Taj Mahal in India, At Hoota Cave in Oman, Nefertari and Tutankhamun tombs in Egypt), aiming utterly to sustain the site or the attraction. This practice is expected to expand to include non-sensitive locations as well for a completely different reason: ensure health precautions, especially social distancing. In this respect, numerous sites and attractions have already reopened after implementing different restrictions such as limiting the number of daily visits (e.g., Eiffel Tower in France), scheduling time-slots for visits (e.g., Louver Museum), locking some partitions or services (e.g., Statue of Liberty in the USA). Attractions such as theme parks, famous squares (e.g., Times Square in New York, Trafalgar Square in London, Puerta del Sol in Madrid), and landmarks that are well-known for attracting mass visits will be at the epicenter of the potential change. The major dilemma of such attractions will be that crowdedness and social interaction have always been a significant part of the tourist's experience; losing this vital component may drive tourists to reconsider visiting these attractions or give them an incomplete experience.

The same endeavor was conducted regarding tourist services such as hotels (e.g., in Red Sea resorts, Egypt), restaurants (e.g., in France, UK, Belgium). Hotels and restaurants will probably drastically change the way they manage guests with usual practices at buffet meals, pools, and beaches under scrutiny (World Economic Forum, 2020a). Such restrictions may not be a serious concern in the coming few months as they will mostly meet with a declined tourist demand. Later on, related authorities will surely need to revise their measurements and restrictions accordingly.

\section{CONCLUSION}

Putting an abrupt end to ten years of sustained growth since the 2009 financial crisis, COVID-19 is undoubtedly an unprecedented crisis that hit tourism heavily; to be, by far, the worst in the historical series of international tourism since 1950 (UNWTO, 2020b). UNWTO reports (2020a, b, \& e) recorded a considerable fall in the number of tourist arrivals in the immediate aftermath of the spread of COVID-19, which resulted in shutting down a significant part of the tourism business. While the tourism 
business was hoping that it will be a temporary setback for the sector, indications reveal that it might be a long-term crisis with future consequences. Although there is no tried and true playbook for recovery from COVID-19 (IATA, 2020c), lessons learned from previous crises imply that the post-COVID-19 period will mostly be associated with numerous concerns and changes.

Travel restrictions exist as the foremost concern as stakeholders are unsure yet about the exact time for lifting these restrictions, even though easing the restrictions is looming in several countries. A definite decline in tourism demand is widely expected as a result of several factors, including the potential economic recession as well as the uncertainty about the potential health risk. The current temporary shutting down of tourist facilities (e.g., restaurants) may turn into a permanent closure due to the cumulative losses, which will result in declining the volume of available services as well as causing a potential loss of experienced workers. Difficulties facing the airline sector will put an additional load on the tourism sector. Finally, misleading information during such time will add more ambiguity to the already confusing environment.

Post-COVID-19 tourists will start traveling domestically before moving to regional destinations. Far distance traveling will come late due to the expected increase in air ticket prices as well as the common aftermath fear of traveling. The destination wellness and health conditions will be at the core of the tourist's attention when making travel decisions. Many tourism services (e.g., hotels, restaurants) will be modified to meet new health requirements. However, tourists will most probably avoid crowded destinations, sites, and attractions, which will reinforce the attractiveness of isolated locations. Unfortunately, hosting communities might see travelers as an additional risk, especially where tourism is not evidently contributing to them. Tourists as well may tend to limit their social interaction with the hosting community to minimize the potentiality of being infected, which may end strengthening the tourism bubbles concept. These changes may reshape tourism and, within time, be the new norm of the tourism sector. Arguing the potentiality of such massive changes to take place necessitates referring to a statement by the Royal Caribbean Cruises Chief Executive, who recalled how drastically travel changed after the 9/11 terrorist attacks and how the "new normal", at that time, eventually just became normal (Sampson \& Compton, 2020). However, further future changes are widely depending on how the pandemic evolves, knowledge of the virus deepens, or science improves (IATA, 2020c).

Bearing in mind that tourism is one of the most - if not the most - impacted sectors, it could be argued that tourism will hardly be able to revive depending on its sole capabilities. In previous less harsh occasions, the UNWTO was typically sought further support from other UN agencies by persuading them to assist the tourism sector since tourism is indispensable for the global economic recovery (UNWTO, 2005).

Finally, crises may have their merits as well. For instance, the post-crisis review will mostly highlight the system deficiencies, which will help to launch new plans for 
improving the destination and enhancing the quality of either tourism product or related services (e.g., alerting systems, health services) (UNWTO, 2005). losing traditional demand may stimulate the destination and tourist enterprises to promote to new segments, which may end expanding their generating markets (Shaw and Williams, 2004). This situation may lead as well to creating new tourism products to meet the potential post-crisis changes in demand.

\section{REFERENCES}

- Aki, S. (1998). A compact econometric model of tourism demand for Turkey. Tourism Management, 19(1), 99-102.

- Amara, D. (2016). Re-branding tourism hotspots after crisis: The case of Sharm El Sheikh, Egypt International Journal of Advanced Scientific Research and Management, 1(11), 35-44.

- BBC (2020, May 14). Coronavirus: Coronavirus may never go away, World Health Organization warns. BBC. Retrieved from https://www.bbc.com/news/world-52643682. [Access on 3 September 2020)

- Blake, A. \& Sinclair, M. (2204). Tourism crisis management: US response to September 11. Annals of Tourism Research, 30(4), 813-832.

- Blazin, N., Gavrilov, M., Markovic, S. \& Hrnjak, I. (2016). The tsunami of December 26, 2004: The impact on tourism trends in Southeast Asia. Environmental Impact, II, 175-186.

- Boukas, N. \& Ziakas, V. (2013). Impacts of the global economic crisis on Cyprus tourism and policy responses. International Journal of Tourism Research, 15, 329345.

- Cheer, J. \& Lew, A. (2017). Understanding tourism resilience: Adapting to social, political, and economic change. In J. Cheer \& A. A. Lew (Eds.). Tourism, resilience, and sustainability: Adapting to social, political, and economic change (pp. 1 - 17). London: Routledge.

- Clements, M. \& Georgiou, A. (1998). The impact of political instability on a fragile tourism product. Tourism Management, 19(3), 283-288.

- Cooper, M. (2005) Japanese Tourism and the SARS Epidemic of 2003. Journal of Travel \& Tourism Marketing, 19(2-3), 117-131.

- Denscombe, M. (1998). The Good research guide: for small-scale social research projects. Buckingham: Open University Press.

- Edgel, D. (1990). International Tourism Policy. New York: Van Nostrand Reinhold.

- Federal Foreign Office (2020). Coronavirus and entry restrictions: 6 things travellers to Germany need to know. Berlin: German Federal Foreign Office. Retrieved from https://tinyurl.com/y7396je3 [Access on 4 September 2020]

- Filimonau, V. \& Coteau, D. (2020). Tourism resilience in the context of integrated destination and disaster management (DM2). International Journal of Tourism Research, 22(2), $202-222$.

- France Diplomacy (2020). Coronavirus - Advice for Foreign Nationals in France. Paris: Ministere de l' Europe et Affaires Etrangeres. Retrieved from https://tinyurl.com/yy6angvp [Access on 3 September 2020] 
- Gov.UK (2020). Coronavirus (COVID-19): Travel corridors. London: UK Government. Retrieved from https://www.gov.uk/guidance/coronavirus-covid-19travel-corridors\#arrival-in-the-uk [Access on 5 September 2020]

- Habibi, F., Rahim, K., Ramchandran, S. \& Chin, L. (2009). Dynamic model for international tourism demand for Malaysia: Panel data evidence. International Research Journal of Finance and Economics, 33, 207-217.

- Hall, M. (2010). Crisis events in tourism: subjects of crisis in tourism. Current Issues in Tourism, 13(2010), 401-417.

- Hanafiah, M. \& Harun, M. (2010). Tourism demand in Malaysia: A cross-sectional pool time-series analysis. International Journal of Trade, Economics, and Finance, 1(1), 80-83.

- Hitchcock, M. \& Putra, I. (2005) The Bali bombings: Tourism crisis management and conflict avoidance. Current Issues in Tourism, 8(1), 62-76.

- Home Affairs (2020). COVID-19 and the border. Sydney: Home Affairs. Retrieved from https://covid19.homeaffairs.gov.au/ [Access on 5 September 2020]

- IATA (2020a). Industry losses to top \$84 billion in 2020. Montreal: International Air Transport Association. Retrieved from https://www.iata.org/en/pressroom/pr/2020-06-09-01/ [Access on 6 September 2020]

- IATA (2020b). COVID-19 latest developments. Montreal: International Air Transport Association. Retrieved from https://www.iata.org/en/pressroom/covid19-news/ [Access on 6 September 2020]

- IATA (2020c). Industry losses to top \$84 billion in 2020. Montreal: International Air Transport Association. Retrieved from https://www.iata.org/en/pressroom/pr/2020-06-09-01/ [Access on 6 September 2020]

- ICAO \& WHO (2020). Joint statement on COVID-19. Montreal: International Civil Aviation Organization. Retrieved from https://www.icao.int/Security/COVID-19/Pages/Statements.aspx [Access on 5 September 2020]

- ICAO (2020). Effects of novel Coronavirus (COVID-19) on civil aviation: Economic impact analysis. Montreal: International Civil Aviation Organization. Retrieved from https://tinyurl.com/y4ouof2d [Access on 5 September 2020]

- ILO (2013). Tourism, poverty reduction, and gender equality. Geneva: International Labour Organization. Retrieved from https://tinyurl.com/y5u5pvuz [Access on 28 August 2020]

- ILO (2017). ILO guidelines on decent work and socially responsible tourism. Geneva: International Labour Organization. Retrieved from https://tinyurl.com/y5yx7tx6 [Access on 28 August 2020]

- ILO (2020). The impact of COVID-19 on the tourism sector. Geneva: International Labour Organization. Retrieved from https://tinyurl.com/y3r4wfla [Access on 28 August 2020] 
- Ioannides, D. \& Apostolopoulos, Y. (1999). Political instability, war, and tourism in Cyprus: Effects, management, and prospects for recovery. Journal of Travel Research, 38(1), $51-56$.

- Jupp, V. (1996). Documents and critical research. In R. Sapsford \& V. Jupp (Eds). Data collection and analysis (pp. 298- 316). London: SAGE publications Ltd.

- Kuto, K. \& Groves, J. (2004). The effect of terrorism: Evaluating Kenya's tourism crisis. E-Review of Tourism Research, 2(4), 88 - 97.

- Lean, H. \& Smyth, R. (2009). Asian financial crisis, Avian Flu, and terrorist threats: Are shocks to Malaysian tourist arrivals permanent or transitory? Asia Pacific Journal of Tourism Research, 14(3), 301-321.

- Mair, J., Ritchie, B. \& Walters, G. (2016). Towards a research agenda for postdisaster and post-crisis recovery strategies for tourist destinations: A narrative review. Current Issues in Tourism, 19(1), 1-26.

- Nunes, A. (2020, July 10). How Covid-19 will change air travel as we know it. $B B C$. Retrieved from https://www.bbc.com/future/article/20200709-how-covid-19will-change-air-travel-as-we-know-it [Access on 9 September 2020]

- OECD (2020). Tourism policy responses to the Coronavirus (COVID-19). Paris: Organisation for Economic Co-operation and Development. Retrieved from https://tinyurl.com/y5tlf3cr [Access on 3 September 2020]

- Ooi, C., Hooy, C. \& Som, A. (2013). Tourism crises and state-level tourism demand in Malaysia. International Journal of Business and Society, 14(3), 376 389.

- Page, S., Song, H. \& Wu, D. (2012). Assessing the impacts of the global economic crisis and Swine Flu on inbound tourism demand in the United Kingdom. Journal of Travel Research, 51(2) 142-153.

- Pambudi, D., McCaughey, N. \& Smyth, R. (2009). Computable general equilibrium estimates of the impact of the Bali bombing on the Indonesian economy. Tourism Management, 30(2), 232-39.

- Papatheodorou, A., Rosselló, J., and Xiao, H. (2010). Global Economic Crisis and Tourism: Consequences and Perspectives. Journal of Travel Research, 49(1) $39-$ 45.

- Patterson, I. (2007). Information sources used by older adults for decision-making about tourist and travel destinations. International Journal of Consumer Studies, 31(2007), 528-533.

- Pforr, C., \& Hosie, P. (2008). Crisis management in tourism: Preparing for recovery. Tourism, Journal of Travel \& Tourism Marketing, 23(2-4), 249-264.

- Pizam, A. \& Mansfield, Y. (1996). Introduction. In A. Pizam \& Y. Mansfield (Eds.). Tourism, Crime, and International Security Issues (pp. 1-17). Chichester: Wiley.

- Punch, K. (1998). Introduction to social research: Quantitative and qualitative approaches. London: SAGE Publications Ltd.

- Ritchie, J., Molinar, C. \& Frechtling, D. (2010). Impacts of the world recession and economic crisis on tourism: North America. Journal of Travel Research, 49(1) 515. 
- Roman, M. (2015). The impact of the global economic crisis tourism in Poland and in selected countries. Journal of Agribusiness and Rural Development, 35(1) 107114

- Salleh, N., Hook, L., Ramachandran, S., Shuib, A. \& Noor, Z. (2008). Asian tourism demand for Malaysia: Abound test approach. Contemporary Management Research, 4(4), 351-368.

- Sampson, H. \& Compton, N. (2020, June 15). 11 ways the pandemic will change travel. Washington Post. Retrieved from https://www.washingtonpost.com/travel/2020/06/15/11-ways-pandemic-willchange-travel/ [Access on 27 August 2020]

- Sausmarez, N. (2004). Malaysia's response to the Asian financial crisis: Implications for tourism and sectoral crisis management. Journal of Travel \& Tourism Marketing, 15(4), 217-231.

- Sekulovic, N. (2015). Trends and new initiatives in tourism at the time of the general economic crisis and the current situation in Serbian tourism. Procedia Economics and Finance, 23(2015) 1628 - 1634.

- Smeral, E. (2009). The impact of the financial and economic crisis on European tourism. Journal of Travel Research, 48(1), 3-13.

- Song, H. \& Lin, S. (2010). Impacts of the financial and economic crisis on tourism in Asia. Journal of Travel Research, 49(1) 16-30.

- Statista (2020). In your opinion, how high is the likelihood of bankruptcy? Statista. Retrieved from https://tinyurl.com/y4t9jeqb [Access on 5 September 2020]

- Strielkowski, W. (2014). Modelling the impact of infectious diseases on tourism. Applied Mathematical Sciences, 8(92), 4571 - 4577.

- UNCTAD (2020). COVID-19 and tourism. Geneva: United Nations Conference on Trade and Development. Retrieved from https://unctad.org/en/PublicationsLibrary/ditcinf2020d3_en.pdf_[Access on 7 September 2020]

- UNWTO (2005). Tsunami: one year on - a summary of the implementation of the Phuket action plan. Madrid: United Nations World Tourism Organization. https://www.e-unwto.org/doi/pdf/10.18111/9789284409259_[Access on 5 September 2020]

- UNWTO (2010). Tourism highlights, 2010. Madrid: United Nations World Tourism Organization. Retrieved from https://www.eunwto.org/doi/pdf/10.18111/9789284413720 [Access on 5 September 2020]

- UNWTO (2011). Tourism towards 2030. Madrid: United Nations World Tourism Organization. Retrieved from https://doi.org/10.18111/9789284414024 [Access on 5 September 2020]

- UNWTO (2013). Tourism highlights, 2013. Madrid: United Nations World Tourism Organization. Retrieved from https://www.eunwto.org/doi/pdf/10.18111/9789284415427 [Access on 5 September 2020]

- UNWTO (2017). Tourism highlights, 2017. Madrid: United Nations World Tourism Organization. Retrieved from https://www.eunwto.org/doi/pdf/10.18111/9789284419029 [Access on 5 September 2020] 
- UNWTO (2019a). International tourism highlights, 2019. Madrid: United Nations World Tourism Organization. Retrieved from https://www.eunwto.org/doi/pdf/10.18111/9789284421152 [Access on 5 September 2020]

- UNWTO (2019b). Ukraine: Country-specific: Basic indicators (Compendium) 2014 - 2018. Madrid: United Nations World Tourism Organization. Retrieved from https://tinyurl.com/y4wbnn5e [Access on 5 September 2020]

- UNWTO (2020a). UNWTO Barometer, January 2020. Madrid: United Nations World Tourism Organization. Retrieved from https://tinyurl.com/y218u388 [Access on 5 September 2020]

- UNWTO (2020b). Impact assessment of the COVID-19 outbreak on international tourism. Madrid: United Nations World Tourism Organization. Retrieved from https://tinyurl.com/vbhq36x [Access on 5 September 2020]

- UNWTO (2020c). International tourist numbers could fall 60-80\% in 2020, UNWTO reports. Madrid: United Nations World Tourism Organization. Retrieved from https://tinyurl.com/y98tku3t [Access on 5 September 2020]

- UNWTO (2020d). 100\% of global destinations now have COVID-19 travel restrictions. Madrid: United Nations World Tourism Organization. Retrieved from https://tinyurl.com/y2g25j4w [Access on 5 September 2020]

- UNWTO (2020e). How are countries supporting tourism recovery? UNWTO briefing note: Tourism and COVID-19. Madrid: United Nations World Tourism Organization. Retrieved from https://www.eunwto.org/doi/pdf/10.18111/9789284421893 [Access on 5 September 2020]

- Wen, Z., Huimin, G. \& Kavanaugh, R. (2005). The impacts of SARS on the consumer behaviour of Chinese domestic tourists. Current Issues in Tourism, 8(1), 22-38.

- Wendt, J. (2019). Comparison of the impact of the Arab spring and terrorist attacks on the decline in tourism in Egypt and Tunisia (2010-2015). Geojournal of Tourism and Geosites, 27(4), 1367-1376.

- WHO (2020a). Timeline of WHO's response to COVID-19. Geneva: World Health Organization. Retrieved from https://www.who.int/news-room/detail/29-06-2020covidtimeline [Access on 7 September 2020]

- WHO (2020b). WHO advice for international travel and trade in relation to the outbreak of pneumonia caused by a new coronavirus in China. Geneva: World Health Organization. Retrieved from https://tinyurl.com/y2dhk8xk [Access on 7 September 2020]

- WHO (2020c). Updated WHO advice for international traffic in relation to the outbreak of the novel Coronavirus 2019-nCoV. Geneva: World Health Organization. Retrieved from https://tinyurl.com/yczy7tdd [Access on 7 September 2020]

- WHO (2020d). Updated WHO advice for international traffic in relation to the outbreak of the novel coronavirus 2019-nCoV. Geneva: World Health Organization. Retrieved from https://tinyurl.com/y6yaqs63 [Access on 7 September 2020] 
- WHO (2020e). Key considerations for repatriation and quarantine of travellers in relation to the outbreak of novel coronavirus 2019-nCoV. Geneva: World Health Organization. Retrieved from https://tinyurl.com/yct67le4 [Access on 7 September 2020]

- WHO (2020f). Updated WHO recommendations for international traffic in relation to COVID-19 outbreak. Geneva: World Health Organization. Retrieved from https://tinyurl.com/s3933d3 [Access on 7 September 2020]

- WHO (2020g). Public health considerations while resuming international travel. Geneva: World Health Organization. Retrieved from https://tinyurl.com/y663mrzu

- Wood, C. (2020, April 19). The coronavirus pandemic has hit the Greek tourism sector hard, with $65 \%$ of hoteliers saying they could face bankruptcy. Business Insider. Retrieved from https://tinyurl.com/y3ldp4qk [Access on 7 September 2020]

- World Bank (2020). International tourism, number of arrivals - France. Washington: World Bank. Retrieved from https://data.worldbank.org/indicator/ST.INT.ARVL?locations=FR_[Access on 2 September 2020]

- World Economic Forum (2020a). 5 ways global travel will change before we find a COVID-19 vaccine. Cologny: World Economic Forum. Retrieved from https://www.weforum.org/agenda/2020/05/global-travel-covid-19-vaccine-holiday/ [Access on 27 August 2020]

- World Economic Forum (2020b). COVID-19: These countries are most at risk from falling tourism. Cologny: World Economic Forum. Retrieved from https://www.weforum.org/agenda/2020/07/coronavirus-covid19-travel-tourism-gdpeconomics/ [Access on 27 August 2020]

- Worldometers (2020). COVID-19 coronavirus pandemic. Worldometers Info. Retrieved from https://www.worldometers.info/coronavirus/_Access on 10 September 2020]

- WTTC (2012). The comparative economic impact of travel \& tourism. London: World Travel \& Tourism Council. Retrieved from https://s3.amazonaws.com/tourismeconomics/craft/Case-Studies-

Docs/The_Comparative_Economic_Impact_of_Travel_Tourism.pdf_[Access on 25 August 2020]

- WTTC (2020a). Recovery scenarios 2020 \& economic impact from COVID-19. London: World Travel \& Tourism Council. Retrieved from https://wttc.org/Research/Economic-Impact/Recovery-Scenarios-2020-EconomicImpact-from-COVID-19 [Access on 25 August 2020]

- WTTC (2020b). Containing the spread of panic is as important as stopping the coronavirus itself, says WTTC. London: World Travel \& Tourism Council. Retrieved from https://wttc.org/News-Article/Containing-the-spread-of-panic-is-as-important-asstoppingthe-coronavirus-itself-says-WTTC. [Access on 25 August 2020] 


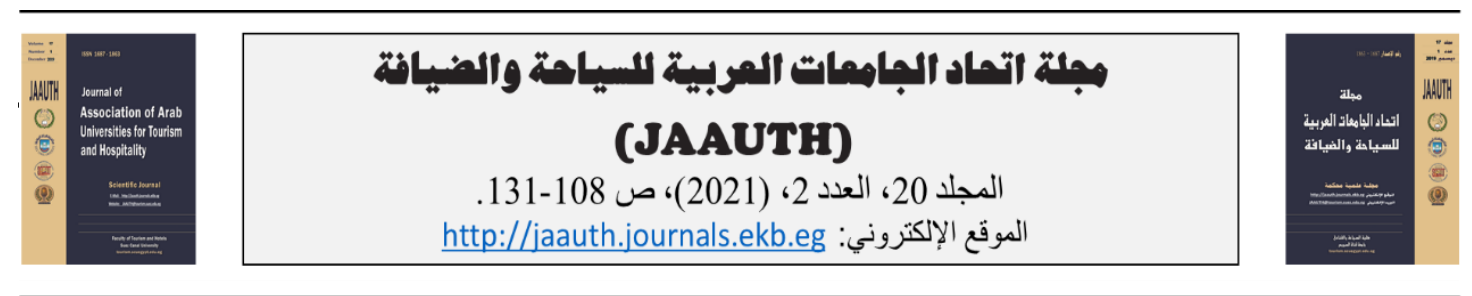

\section{السياحة الجديدة ما بعد كوفيا 19}

جلال عفيفى

كلية الأداب والعلوم الاجتماعية، جامعة السلطان قابوس؛ كلية السياحة والفنادق، جامعة حلوان.

\begin{tabular}{|c|c|}
\hline & \\
\hline 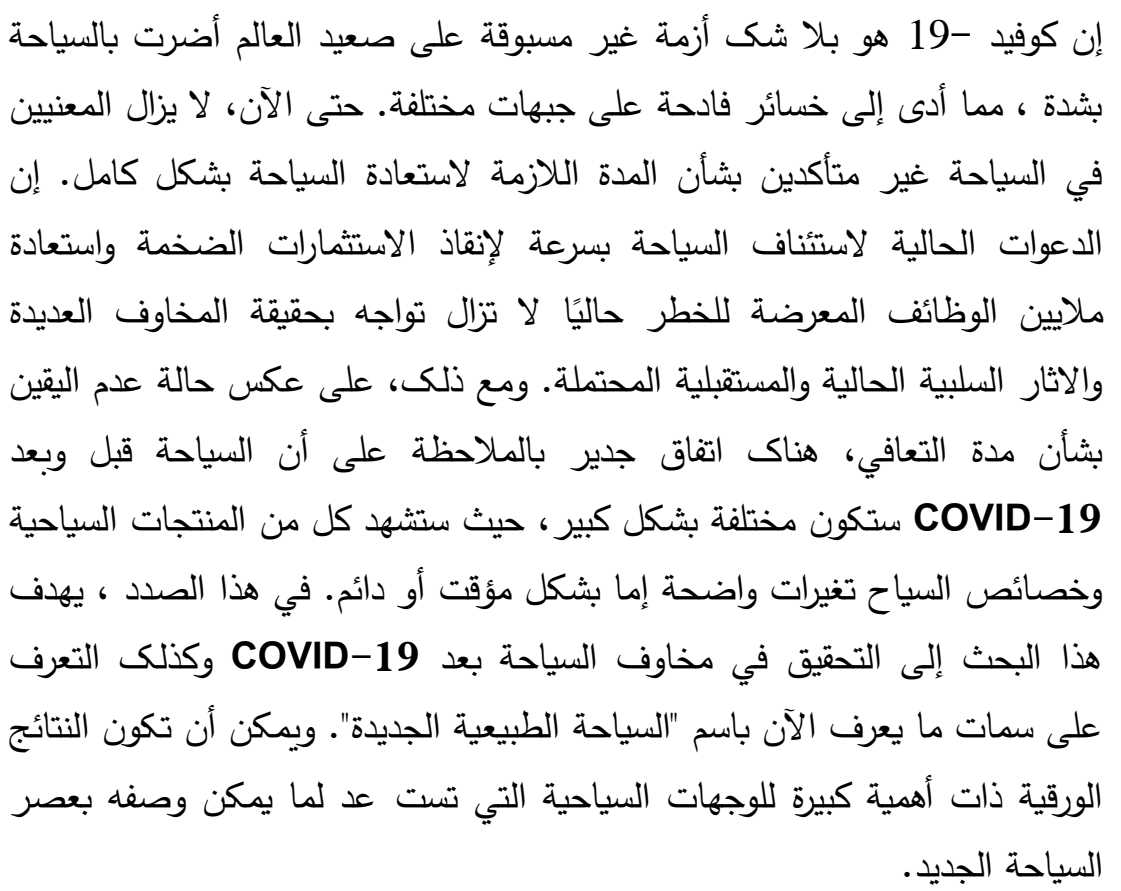 & 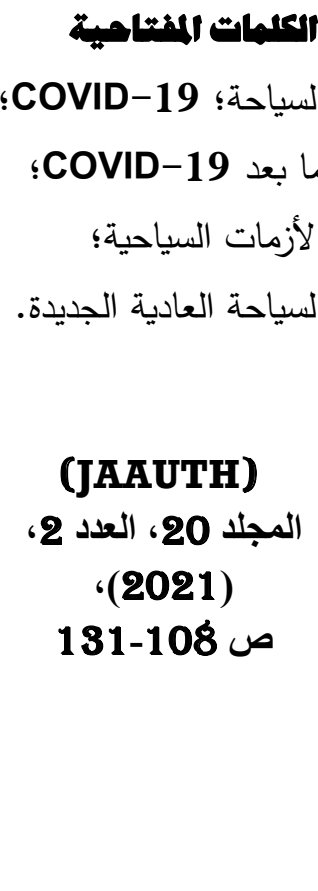 \\
\hline
\end{tabular}

